\title{
PELATIHAN BRANDING SEKOLAH PADA SOSIAL MEDIA DI SMP IT MADANI
}

\author{
Wenni Syafitri*1, Loneli Costaner ${ }^{2}$ \\ ${ }^{1,2}$ Program Studi Teknik Informatika, Fakultas Ilmu Komputer, Universitas Lancang Kuning \\ Jl. Yos Sudarso KM. 8 Rumbai, Pekanbaru, (0761) 52248, 53108 \\ *E-mail: wenni20@gmail.com
}

\begin{abstract}
SMP IT Madani has 10 teachers and 99 students till now. To improve the promotion of SMP IT Madani, various promotional activities have been carried out, one of which is the expo. Evaluation mechanism is not done optimally for promotion. Inappropriate promotion mechanism and evaluation that is not optimal, so that it will impact on school branding. Branding is a mechanism to highlight what is characteristic of the school as well as being a place for school promotion. The target of community service is to realize the school branding training for teachers and school management using information technology to the fullest. This activity has been successfully implemented, step by step carried out carefully. This activity also succeeded in carrying out knowledge transfer activities to our partners, namely SMP IT Madani. Knowledge transferred is how to do effective school branding. The evaluation of this activity is a measurement using the Guttman scale. The evaluation results show success by obtaining a value of 1 for each CS and $C R$ scale.
\end{abstract}

Keywords - Branding, Information Technology, Social Media

\begin{abstract}
Abstrak
SMP IT Madani memiliki jumlah guru 10 orang dan jumlah siswa hingga saat ini 99 orang. Untuk meningkatkan promosi SMP IT Madani, berbagai kegiatan promosi telah dilaksanakan, salah satunya yaitu ekspo. Mekanisme evaluasi tidak dilakukan secara maksimal untuk promosi. Mekanisme promosi yang tidak tepat serta evaluasi yang dilakukan tidak maksimal, sehingga akan berimbas pada branding sekolah. Branding merupakan suatu mekanisme untuk menonjolkan apa yang menjadi ciri khas dari sekolah sekaligus menjadi ajang promosi sekolah. Target pengabdian masyarakat ini yaitu melakukan realisasi terhadap pelatihan branding sekolah kepada guru dan manajemen sekolah menggunakan teknologi informasi secara maksimal. Kegiatan pengabdian ini telah berhasil dilaksanakan, tahap demi tahap dilaksanakan secara cermat. Kegiatan ini juga berhasil melakukan kegiatan transfer pengetahuan kepada mitra kami, yaitu SMP IT Madani. Pengetahuan yang ditransfer yaitu bagaimana melakukan branding sekolah yang efektif. Evaluasi dari kegiatan ini berupa pengukuran menggunakan skala guttman. Hasil evaluasi menunjukkan keberhasilan dengan memperoleh nilai 1 untuk setiap skala CS dan CR.
\end{abstract}

Kata kunci-Branding, Teknologi Informasi, Sosial Media

\section{PENDAHULUAN}

Sekolah Menengah Pertama Islam Terpadu Madani lebih dikenal SMP IT MADANI, merupakan

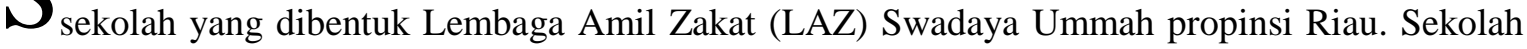
ini bebas biaya apapun. Sekolah ini berdiri tahun 2011 dan jumlah siswa pertama kali hampir 20 orang. Hingga saat ini, SMP IT MADANI memiliki jumlah guru 10 orang dan jumlah siswa mencapai 99 orang. Dana operasional sekolah murni dari donasi masyarakat melalui LAZ Swadaya Ummah bersumber dari zakat, infaq dan waqaf.

Visi SMP IT Madani yaitu "Menjadi model lembaga pendidikan dalam pemberdayaan kaum Dhuafa yang melahirkan generasi Qur'an mandiri dan berprestasi". Keterbatasan fasilitas dan hal lainnya tidak membuat surut langkah SMP IT Madani untuk terus menjaga komitmen serta 
konsisten menghasilkan karya dan prestasi. Prestasi tidak dapat dihalangi oleh keterbatasan yang ada, namun keterbatasan menjadi cambuk untuk dapat berkompetisi dengan sekolah lain.

Kurikulum yang dilaksanakan oleh SMP IT Madani adalah Kurikulum Dinas Pendidikan dan Jaringan Sekolah Islam Terpadu (JSIT). Konsep pembelajaran lain juga diterapkan pada sekolah ini, seperti Project Base Learning (PBL). Murid-murid juga mendapatkan kegiatan pembelajaran lainnya, seperti Ekskul (Renang, Karate, Pramuka dan Futsal), Mentoring, Madani Expo, Field Trip, Bakti Masjid, I'Tikaf Ramadhan. Siswa-siswa SMP IT Madani juga aktif mengikuti berbagai kegiatan seperti Tahfizul Alquran, Olimpiade Matematika, English Club dan Menulis.

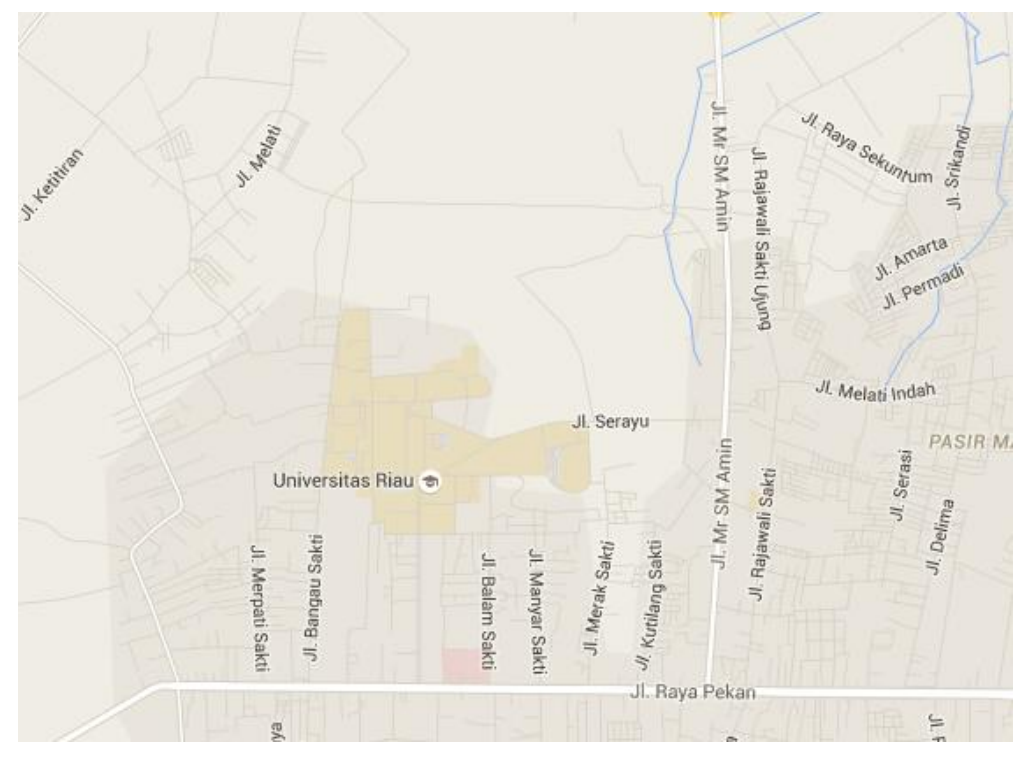

Gambar 1 Lokasi Mitra

Penggunaan Sosial Media membuat jarak antara pihak institusi yang memperkenalkan aktifitas institusi kepada pihak yang tertarik menjadi lebih dekat. Zaman sekarang, masyarakat dunia maya lebih menyukai untuk menggunakan sosial sebagai media penyampaian informasi kegiatan-kegiatan yang dilaksanakan institusi, ciri khas yang dimiliki oleh institusi. SMP IT Madani telah memiliki sosial media sebagai media penyebar informasi terkait kegiatan dan ciri khas yang dimiliki SMP IT Madani yaitu facebook. Beberapa kegiatan telah dibagikan oleh SMP IT Madani.

SMT IT Madani memiliki target untuk mendapatkan calon siswa yang memiliki kemampuan akademik bagus tetapi lemah perekonomiannya. Jika penggunaan Mekanisme promosi yang tidak tepat serta evaluasi yang tidak maksimal yang dilakukan, akan berimbas kepada tidak tercapainya target sekolah. Branding merupakan suatu mekanisme untuk menonjolkan apa yang menjadi ciri khas dari sekolah sekaligus menjadi ajang promosi sekolah.

Ciri khas dari SMP IT Madani yaitu sekolah yang bebas biaya bagi keluarga yang tidak mampu. Oleh karena itu berbagai kegiatan dilakukan untuk meningkatkan promosi sekolah seperti melakukan ataupun mengikuti kegiatan expo sekolah gratis. Branding yang tidak tepat akan berdampak kepada pencapaian target sekolah. Namun, nilai-nilai ciri khas yang dimiliki oleh SMP IT Madani belum dikelola dengan baik dan sesuai dengan standar branding dan teknik desain grafis. Hal ini terlihat dari dua gambar berikut ini. 

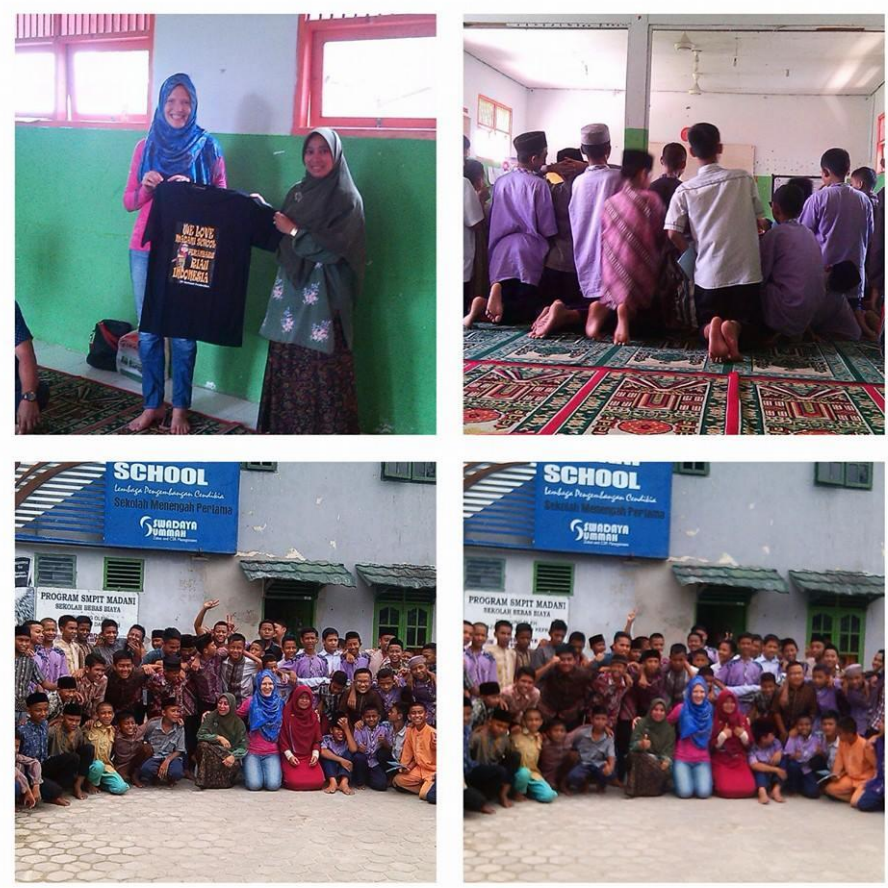

Gambar 2 Salah satu aktivitas SMP IT Madani

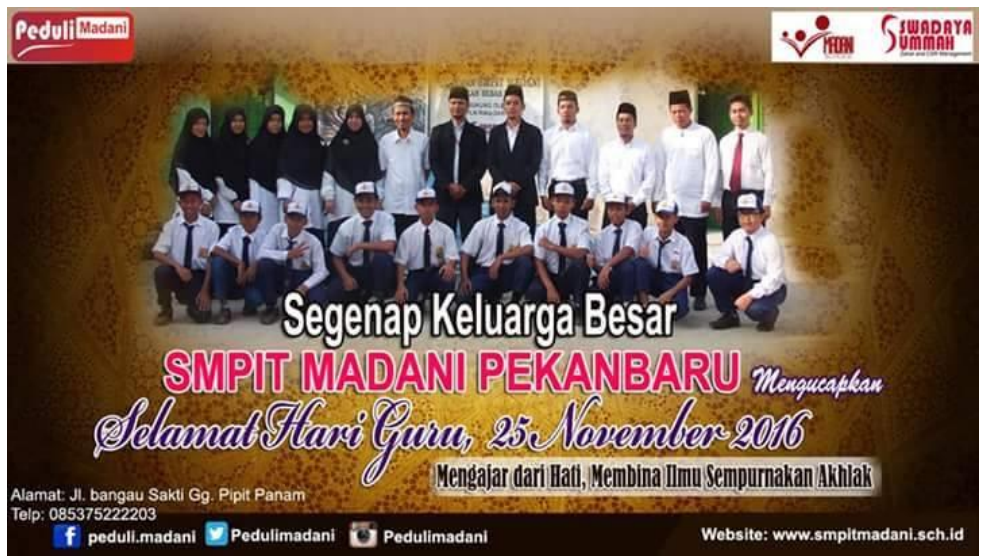

Gambar 3 Salah satu aktivitas SMP IT Madani

\section{TARGET DAN LUARAN}

Target yang ingin dicapai pada kegiatan Pengabdian Kepada Masyarakat ini yaitu melakukan realisasi terhadap pelatihan branding sekolah kepada guru dan manajemen sekolah menggunakan teknologi informasi secara maksimal. Landasan solusi dan target ini berdasarkan rekomendasi dari [1]-[10].

Dalam hal ini mitra yang dirangkul adalah:

Mitra adalah minimal 5 Guru beserta manajemen dari SMP IT Madani. Sementara luaran yang hendak dihasilkan adalah Guru dan staf Tata Usaha dapat melakukan branding sekolah dengan menggunakan teknologi informasi secara maksimal. Berikut kriteria luaran yang diinginkan:
A. Mengetahui konsep dasar dari branding
B. Membuat branding SMP IT Madani.
C. Membuat mekanisme branding yang terintegrasi dengan perangkat teknologi informasi. 
Untuk menilai keberhasilan luaran adalah sebagai berikut :

A. $90 \%$ peserta yang diundang hadir dalam pelatihan.

B. Terlaksananya seluruh kegiatan branding sekolah.

C. $75 \%$ peserta mampu menguasai branding sekolah menggunakan teknologi informasi.

D. Membantu guru dan pihak manajemen terwujud branding sekolah.

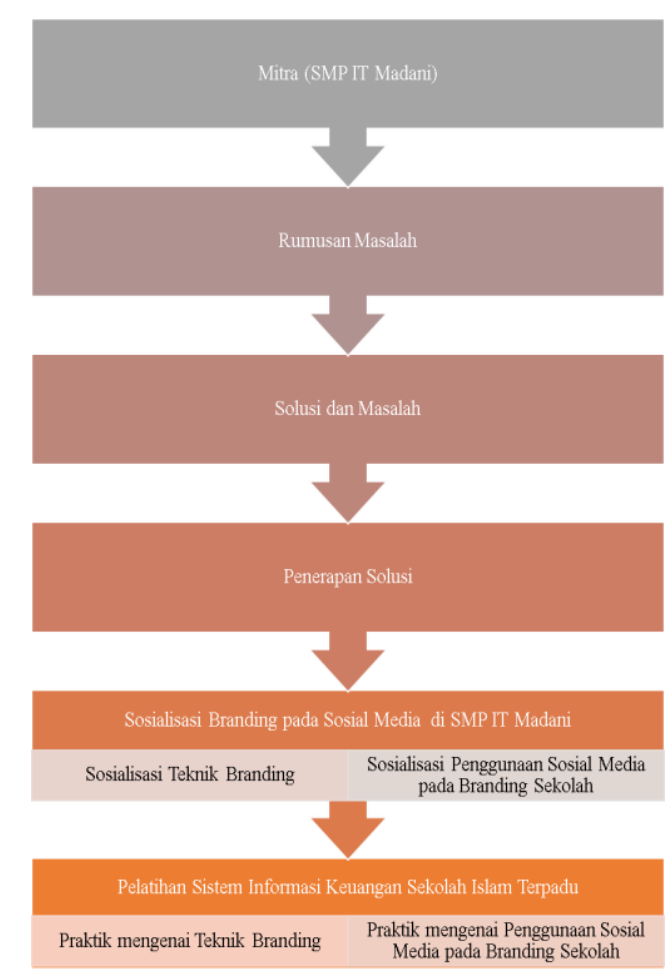

Gambar 4 transfer pengetahuan yang akan dilakukan

\section{METODE DAN PELAKSANAAN}

\section{Pendahuluan}

Pelatihan branding sekolah menggunakan teknologi informasi berdasarkan permasalahan pihak manajemen dan guru untuk memaksimalkan media promosi sekolah. Berikut faktor yang dapat mempengaruhinya, antara lain:

A. Guru serta staf Tata Usaha paham akan penggunaan teknologi informasi, namun tidak untuk memaksimalkan penggunaannya.

B. Guru dan staf Tata Usaha memiliki ide promosi kepada social media, namun tidak memiliki ciri khas dari sekolah atau branding.

\section{Pendekatan Solusi}

Solusi yang ditawarkan adalah mengajarkan kepada guru dan pihak manajemen bagaimana memaksimalkan penggunaan teknologi informasi dengan melakukan kolaborasi dengan branding sekolah, sehingga mindset pihak sekolah dapat berobah mengenai konsep promosi sekolah yang tepat guna.

\section{Prosedur Kerja}

Sosialisasi dan pelatihan dilakukan dengan mengikuti prosedur berikut ini:

A. Mengusulkan kegiatan Pengabdian Kepada Masyarakat ke LPPM

B. Mengurus dan menyiapkan segala kebutuhan administrasi.

C. Mengirim surat ke Kepala Sekolah SMP IT Madani untuk mengikuti pelatihan. 
D. Mengirim surat undangan ke SMP IT Madani agar mengutus 6 orang guru, 2 orang staf Tata Usaha.

E. Menyiapkan modul pelatihan

F. Melakukan sosialisasi dan pelatihan Branding Sekolah

G. Melakukan evaluasi terhadap keberhasilan Pengabdian Kepada Masyarakat

\section{Rencana Kegiatan}

Rencana kegiatan sosialisasi dan pelatihan dilakukan selama 2 Jam dengan rincian kegiatan sebagai berikut:

Pukul 09.00-10.00 (Pengenalan apa itu branding)

Pukul 10.00-12.00 (Kolaborasi teknologi informasi dengan branding)

Selanjutnya setelah pelatihan dilakukan, diharapkan kepada peserta dapat memaksimalkan branding sekolah dengan menggunakan teknologi informasi.

\section{KELAYAKAN TIM PELAKSANA}

\section{Kinerja Tim Pelaksana}

Kegiatan Pegabdian Kepada Masayarakat ini diketuai oleh Wenni Syafitri, S.T., M.T.I yang sudah lama terlibat dan berpengalaman dalam kegiatan akademik, penelitian dan pengabdian pada masyarakat. Berikut ini riwayat pengabdian masyarakat yang telah dilakukan.

Tabel 1Riwayat Ketua Tim Pengabdian Kepada Masyarakat

\begin{tabular}{lclcc}
\hline No. & Tahun & \multicolumn{1}{c}{ Judul Pengabdian Kepada } & \multicolumn{2}{c}{ Pendanaan } \\
\cline { 3 - 5 } & \multirow{2}{*}{2016} & $\begin{array}{l}\text { Masyarakat } \\
\text { Workshop Aplikasi Bank Soal Dan Test }\end{array}$ & Mandiri & Jml (Juta Rp) \\
\hline \multirow{2}{*}{2017} & $\begin{array}{l}\text { Online Pada Sekolah Menengah Islam } \\
\text { Terpadu Daerah Pekanbaru }\end{array}$ & & \\
\hline & $\begin{array}{l}\text { Training Instalasi Dan Pengelolaan } \\
\text { Maintenance Jaringan Komputer Pada } \\
\text { Sekolah Islam Terpadu Pekanbaru }\end{array}$ & APBF & $3.000,-$ \\
\hline \multirow{3}{*}{2018} & $\begin{array}{l}\text { Pelatihan Dan Sosialisasi Sistem } \\
\text { Informasi Keuangan Pada Sekolah Islam } \\
\text { Terpadu Pekanbaru }\end{array}$ & Institusi & $5.000 .000,-$ \\
\hline
\end{tabular}

\section{Kepakaran}

Kegiatan Pengabdian Kepada Masyarakat ini membutuhkan kepakaran dibidang branding, dengan pembagian topik sebagai berikut:

A. Pengantar pelatihan branding sekolah dengan tema "Apa itu Branding" akan disampaikan oleh Loneli Costaner, M.Kom

B. Pelatihan branding sekolah yang terdiri dari Kolaborasi teknologi informasi dengan branding, disampaikan oleh Wenni Syafitri, MT,.M.T.I

\section{HASIL DAN LUARAN YANG DICAPAI}

Kegiatan ini dilaksanakan melalui dua mekanisme tahapan sebagai berikut:

\section{Tahap Satu : Sosialisasi}

SMP IT Madani hingga kegiatan ini dilaksanakan belum menemukan Teknik yang tepat untuk menjaring siswa secara maksimal. Kegiatan ini mendapatkan apresiasi baik sekali dari pihak 
sekolah. Besar harapan mereka untuk pelaksanaan kegiatan ini berjalan dengan lancar, sehingga ilmu yang diperoleh dapat diimplementasikan.

\section{Tahap Dua : Pelatihan}

Kegiatan pelatihan branding sekolah dilakukan secara sistematis. Langkah awal dilakukan sesi presentasi dan terakhir dilakukan workshop kegiatan. Kegiatan ini dilaksanakan pada hari Sabtu tanggal 12 Januari 2019. Acara ini dimulai pada pukul 09.00 WIB hingga 13.00 WIB di SMP IT Madani.

Berhasilnya suatu kegiatan harus dapat diukur, oleh karena itu kegiatan ini menggunakan kuisioner untuk mengambil informasi tentang keberhasilan kegiatan. Kuisioner ini dilaksanakan sebelum mulai kegiatan (PRE-TEST) dan diakhir kegiatan (POST-TEST). Jumlah butir kuisioner sebanyak 6 buah untuk kuisioner POST dan PRE-TEST. Sifat kuisioner ini hanya membutuhkan jawaban Ya dan Tidak untuk menjawab pertanyaan. Hasil kuisioner diolah menggunakan skala guttman [11].

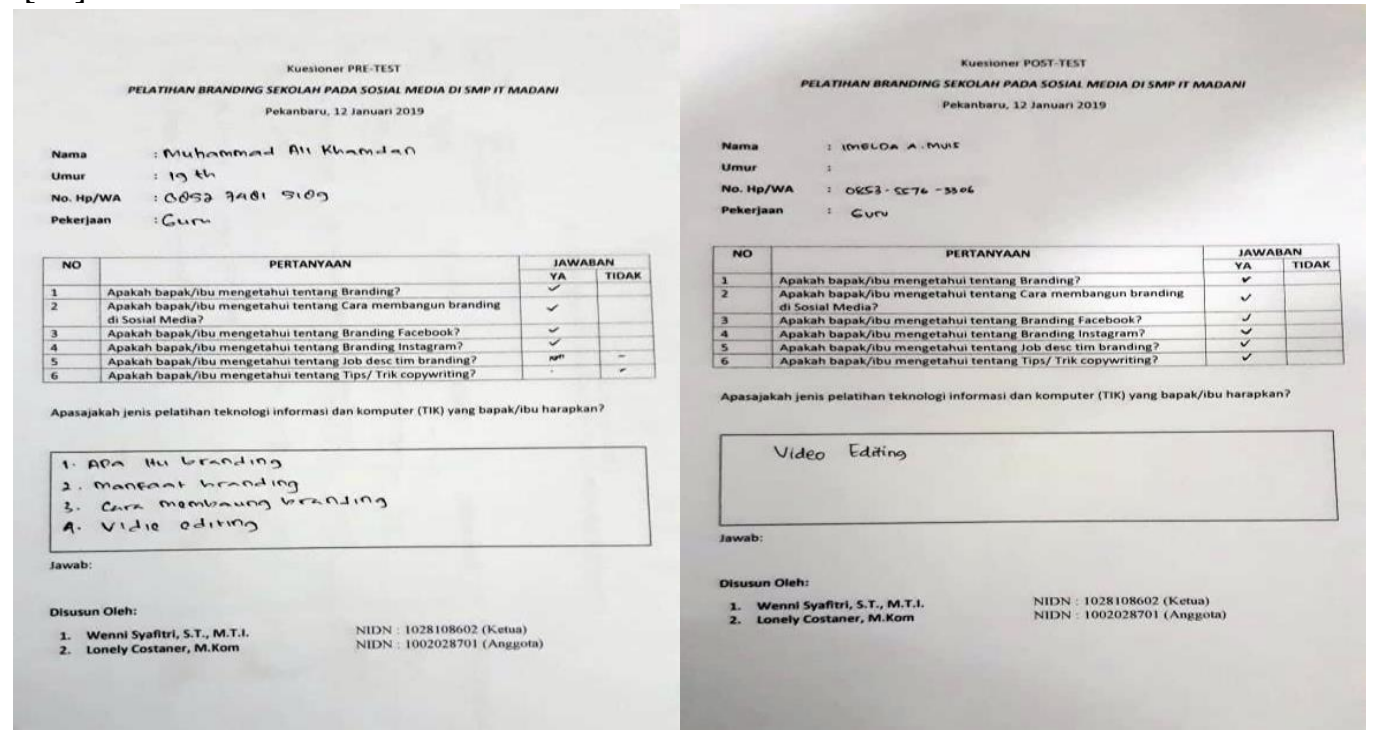

Gambar 5 Kuisioner Pre-Test \& Post-Test

\section{Koefisien Reprodusibilitas (CR)}

Validitas kuisioner menggunakan CR, CR Merupakan tingkat kehandalan dari pengukuran terhadap nilai yang diperoleh dari kuisioner. nilai CR yang dapat diterima yaitu $\geq 0.90$ [11].

Rumus:

$C R=1-\left(\frac{T E}{P E}\right)$

Keterangan:

$\mathrm{TE}=$ Jumlah eror

$\mathrm{PE}=$ Jumlah eror yang kemungkinan terjadi.

\section{Koefisien Skalabilitas (CS)}

CS mampu mengukur jika terjadi penyimpangan pada CR pada batas yang masih dapat diterima. Nilai CS yang baik yaitu $\geq 0.60$ [11].

$$
C S=1-\left[\frac{T E}{T E x Z}\right]
$$

Keterangan: 
TE $=$ Jumlah eror

$\mathrm{Z}=$ Jumlah Kesalahan yang diterapkan

$\mathrm{Tn}=$ Jumlah Pilihan Jawaban

Berikut hasil penilaian terhadap kuisioner PRE-TEST.

Tabel 2. Hasil Pre-Test

\begin{tabular}{|c|c|c|c|c|c|c|c|c|c|}
\hline NO & VA1 & VA2 & VA3 & VA4 & VA5 & VA6 & Jumlah & Error \\
\hline $\mathbf{1}$ & 1 & 1 & 1 & 1 & 2 & 1 & 7 & \\
\hline $\mathbf{2}$ & 2 & 2 & 2 & 2 & 2 & 2 & 12 & \\
\hline $\mathbf{3}$ & 2 & 2 & 2 & 2 & 2 & 2 & 12 & \\
\hline $\mathbf{4}$ & 2 & 2 & 2 & 2 & 2 & 2 & 12 & \\
\hline $\mathbf{5}$ & 1 & 1 & 1 & 1 & 2 & 2 & 8 & \\
\hline
\end{tabular}

Tabel 3. Sebaran nilai kuisioner PRE-TEST

\begin{tabular}{|c|c|c|}
\hline Responden & YA & TIDAK \\
\hline $\mathbf{1}$ & 5 & 1 \\
\hline $\mathbf{2}$ & 0 & 6 \\
\hline $\mathbf{3}$ & 0 & 6 \\
\hline $\mathbf{4}$ & 0 & 6 \\
\hline $\mathbf{5}$ & 4 & 2 \\
\hline
\end{tabular}

Berdasarkan Error! Reference source not found., Jumlah responden sebanyak 5 orang, 6 buah butir pertanyaan dan tidak terdapat nilai error pada setiap jawaban pertanyaan. Berdasarkan rumus CR maka nilai yang diperoleh adalah 1, dan nilai CS adalah 1 . Hal ini berarti butir pertanyaan handal dan dapat dilanjutkan untuk pengambilan informasi dari responden.

Berikut hasil pengambilan data pada tahap POST-TEST.

Tabel 4. Hasil Post Test

\begin{tabular}{ccccccccc}
\hline NO & VA1 & VA2 & VA3 & VA4 & VA5 & VA6 & Jumlah & Error \\
$\mathbf{1}$ & 1 & 1 & 1 & 1 & 1 & 1 & 6 & 0 \\
$\mathbf{2}$ & 1 & 1 & 1 & 1 & 1 & 1 & 6 & 0 \\
$\mathbf{3}$ & 1 & 1 & 1 & 1 & 1 & 1 & 6 & 0 \\
$\mathbf{4}$ & 1 & 1 & 1 & 1 & 1 & 1 & 6 & 0 \\
$\mathbf{5}$ & 1 & 1 & 1 & 1 & 1 & 1 & 6 & 0 \\
& & & \multicolumn{2}{c}{ Jumlah } & & & 30 & 0 \\
\hline
\end{tabular}

Tabel 5. Sebaran nilai kusioner POST-TEST

\begin{tabular}{|c|c|c|}
\hline Responden & YA & TIDAK \\
\hline $\mathbf{1}$ & 6 & 0 \\
\hline $\mathbf{2}$ & 6 & 0 \\
\hline $\mathbf{3}$ & 6 & 0 \\
\hline $\mathbf{4}$ & 6 & 0 \\
\hline $\mathbf{5}$ & 6 & 0 \\
\hline
\end{tabular}

Berdasarkan Error! Reference source not found., Jumlah responden sebanyak 5 orang, 6 buah butir pertanyaan dan tidak terdapat nilai error pada setiap jawaban pertanyaan. Berdasarkan 
rumus CR maka nilai yang diperoleh adalah 1, dan nilai CS adalah 1 . Hal ini berarti butir pertanyaan handal dan dapat dilanjutkan untuk pengambilan informasi dari responden.

\section{Evaluasi Hasil}

Kegiatan ini telah membuahkan hasil yang maksimal, hal ini terbukti dari hasil pengukuran kuisioner PRE-TEST dan POST-TEST untuk nilai CS dan CR adalah 1. Dengan demikian kegiatan ini telah berhasil dan diharapkan dapat dimanfaatkan bagi peserta kegiatan.

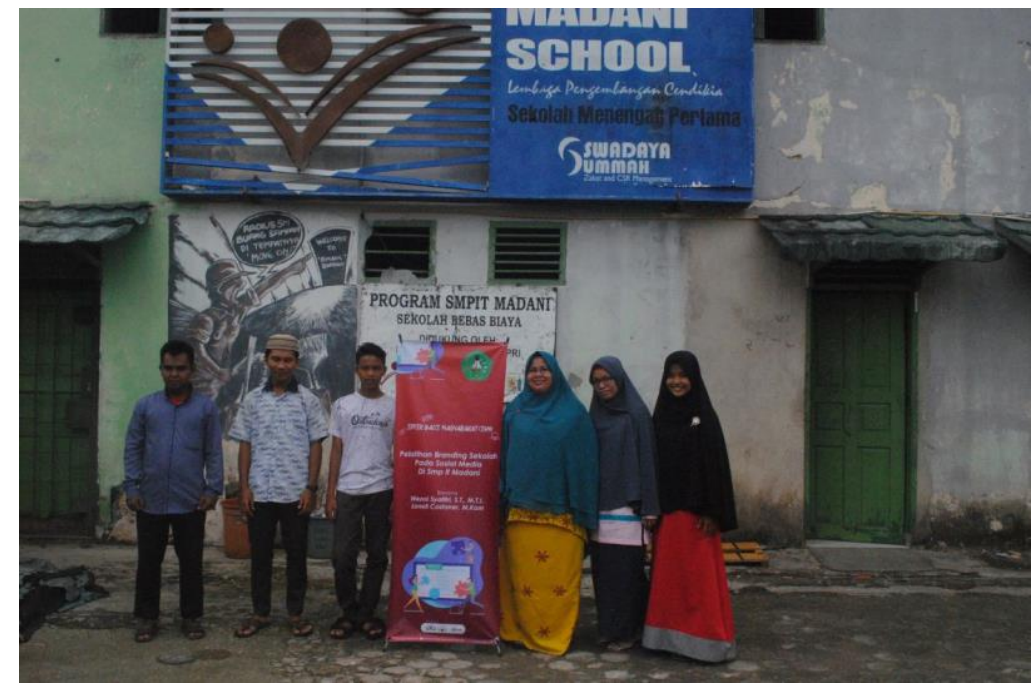

Gambar 6. Bersama Peserta kegiatan

\section{KESIMPULAN}

Kegiatan pengabdian ini telah berhasil dilaksanakan, tahap demi tahap dilaksanakan secara cermat. Kegiatan ini juga berhasil melakukan kegiatan transfer pengetahuan kepada mitra kami, yaitu SMP IT Madani. Pengetahuan yang ditransfer yaitu bagaimana melakukan branding sekolah yang efektif. Evaluasi dari kegiatan ini berupa pengukuran menggunakan skala guttman. Hasil evaluasi menunjukkan keberhasilan dengan memperoleh nilai 1 untuk setiap skala CS dan CR.

\section{SARAN}

Kegiatan yang telah terlaksana ini hendaknya segera diterapkan agar terlihat hasil dari kegiatan yang telah dilaksanakan.

\section{UCAPAN TERIMA KASIH}

Penulis mengucapkan terima kasih kepada Universitas Lancang Kuning yang telah memberi bantuan terhadap kegiatan pengabdian masyarakat ini.

\section{DAFTAR PUSTAKA}

[1] M. Bampo, M. T. Ewing, D. R. Mather, D. Stewart, and M. Wallace, "The effects of the social structure of digital networks on viral marketing performance," Inf. Syst. Res., vol. 19, no. 3, pp. 273-290, 2008.

[2] T. Bishop and J. Rowley, "Digital marketing in independent libraries in the United Kingdom," J. Librariansh. Inf. Sci., vol. 45, no. 4, pp. 323-334, 2013.

[3] D. J. Faulds and W. G. Mangold, "Developing a Social Media and Marketing Course," Mark. Educ. Rev., vol. 24, no. 2, pp. 127-144, Jul. 2014. 
[4] B. Ghosh and A. Stock, "Advertising Effectiveness, Digital Video Recorders, and Product Market Competition," Mark. Sci., vol. 29, no. 4, pp. 639-649, Jul. 2010.

[5] P. K. Kannan and H. "Alice" Li, "Digital marketing: A framework, review and research agenda," Int. J. Res. Mark., vol. 34, no. 1, pp. 22-45, Mar. 2017.

[6] M. M. Mariani, M. Di Felice, and M. Mura, "Facebook as a destination marketing tool: Evidence from Italian regional Destination Management Organizations," Tour. Manag., vol. 54, pp. 321-343, Jun. 2016.

[7] E. W. T. Ngai, "Internet marketing research (1987-2000): a literature review and classification," Eur. J. Mark., vol. 37, no. 1/2, pp. 24-49, Feb. 2003.

[8] A. Persaud and I. Azhar, "Innovative mobile marketing via smartphones," Mark. Intell. Plan., vol. 30, no. 4, pp. 418-443, Jun. 2012.

[9] M. Rogers, C. Chapman, and V. Giotsas, "Measuring the diffusion of marketing messages across a social network," J. Direct, Data Digit. Mark. Pract., vol. 14, no. 2, pp. 97-130, Nov. 2012.

[10] Y. Yang, Y. C. Yang, B. J. Jansen, and M. Lalmas, "Computational Advertising: A Paradigm Shift for Advertising and Marketing?," IEEE Intell. Syst., vol. 32, no. 3, pp. 3-6, May 2017.

[11] R. J. Howell, "The Guttman Approach to Modeling Drug Sequences :," vol. 6, no. 3, pp. 1-15, 2010. 